\title{
melanoma in situ
}

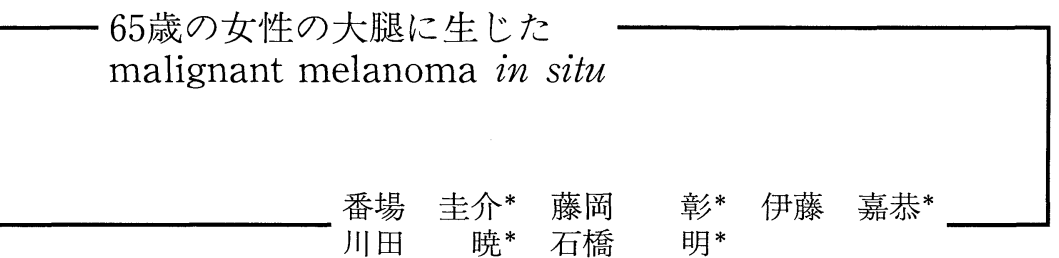

\section{Summary}

A 65 years old woman with malignant melanoma in situ, measuring $4 \mathrm{~mm}$ in diameter, was examined. She presented with slowly growing brown, flat lesion on the left tigh of 1 year duration. The edge of the lesion was irregular, and its color was variegated dark brown in center and lower end to brown in periphery. Histopathological findings showed the lesion to be asymmetrical with unsharp lateral margins and mild inflammatory infiltrates in the upper dermis. Rete ridges were slightly elongated and there were tumor cells with atypical nuclei nested and scattered in the lowere epidermis. The tumor cells reacted strongly to monoclonal anti-HMB-45 antibody.

Key words : Melanoma in situ, $4 \mathrm{~mm}$ in diameter, Early melanoma, HMB-45

\section{はじめに}

悪性黒色腫の早期診断基準として, 病変の最 大径が $6 \mathrm{~mm}$ 以上あることが一つの目安とされ ている。しかし, 今回最大径 $4 \mathrm{~mm}$ と非常に小さ いものの, 臨床的に malignant melanoma（以 下 MM）が疑われ, 組織学的に MM in situ と 診断しえた症例を経験したので，若干の文献的 考察を含めて報告する。

\section{症例}

患 者：65歳，女性

* Keisuke BANBA, Akira FUJIOKA, Yoshiyasu ITO, Akira KAWADA, Akira ISHIBASHI : 防 衛医科大学校皮膚科学教室
初 診：1997年 3 月 10 日

主 訴: 左大腿の褐色斑

既往歴，家族歴：特記すべきことはない。

現病歴：初診の約 1 年前から粟粒大の左大腿 の色素斑に気付いていたが放置していた。しか し，最近やや拡大してきたため当科を受診した。

現 症：左大腿伸側上方に $4 \times 3 \mathrm{~mm}$ 大の辺 緑が不整形かつ非対称性の褐色斑があり，その 中央部と下端は, 色調がさらに濃く黒褐色を呈 し，色調は 2 段階となっていた。中央の色調の 濃い部分は，周囲より僅かながら隆起していた （図 1)。痒みなど自覚症状はない。

治療および経過：臨床的に MMの早期病変 を疑って, 辺縁から $5 \mathrm{~mm}$ 以上離し, 皮下脂肪ま で含め全摘した。切除後 6 力月経過した現在ま で再発はみられない。また，化学療法は施行し ていない。

病理組織学的所見：病変部に一致して表皮, 
特に基底層に沿って明るい胞体と大型の核を有 するメラノサイトが個別性あるいは集簇性に増 生しており, さらに中央の軽度隆起部に一致し て軽度ながら表皮突起の延長が認められた。真 皮浅層にはリンパ球浸潤と多数のメラノファー ジが観察された(図 2)。拡大すると増生したメ ラノサイトの核は大小不同の不整な形態を示 し，核小体が明暸で異型性が強く，胞体は類円 形や紡錘形と多様であった。これらのメラノサ イトは基底層にかなり密に増生し, 所により集 簇して胞巣を形成しつつあると思われる所見も

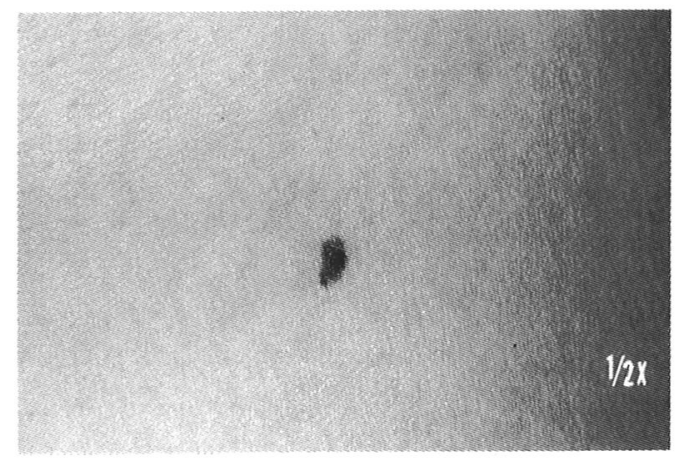

図 1. 初診時臨床像

左大腿伸側上方に $4 \times 3 \mathrm{~mm}$ 大の辺縁が不整 形かつ非対称性の褐色斑があり，その中央部 と下端は色調がさらに濃く, 黒褐色を呈して いた

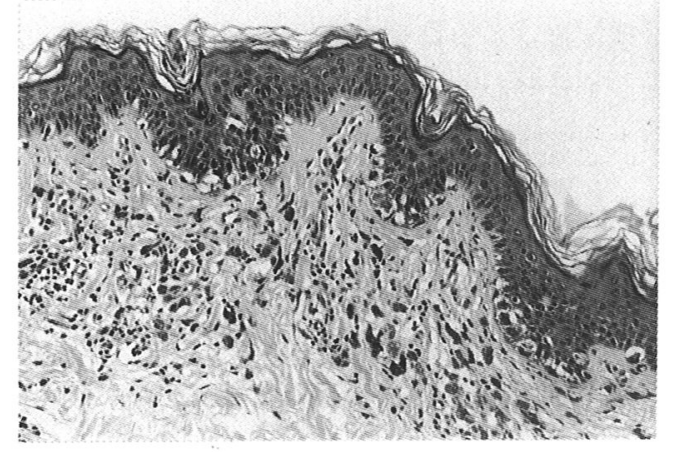

図 3.病変の組織像 $($ H.E.染色 $\times 200)$

メラノサイトの核は大小不同の不整な形態を 示し, 核小体が明膫で異型性が強く, 胞体は類 円形や紡錘形と多様であった
みられた(図 3 )。しかし, 表皮上層への増生は なく，真皮内への浸潤も認めなかったが，これ らメラノサイトの色素産生は著明に元進してい て, 放出されたメラニン顆粒が角層内にも残留 してみられた(図 4)。パラフィン切片を用いた ABC 法 (avidin-biotin complex method)によ る免疫組織化学的検索では, 抗 HMB-45抗体 で，異型メラノサイトの細胞質に一致して陽性 コントロールの MM と同程度の強い陽性所見 を示した(図 5)。陰性コントロールの母斑細胞 性母斑は，一部でのみ弱陽性であった。

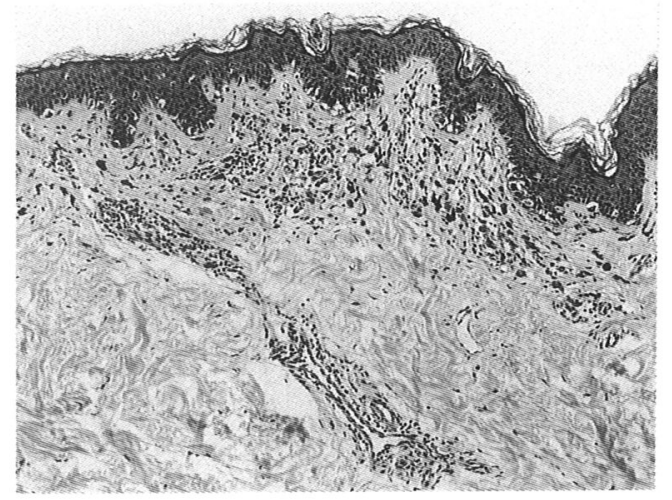

図 2.病変の組織像 $($ H.E.染色 $\times 100)$

病変部に一致して表皮，とくに基底層に沿っ て明るい胞体と大型の核を有するメラノサイ トが個別性に増生し, 一部では集簇して胞巣 を形成しつつあるようにみられた

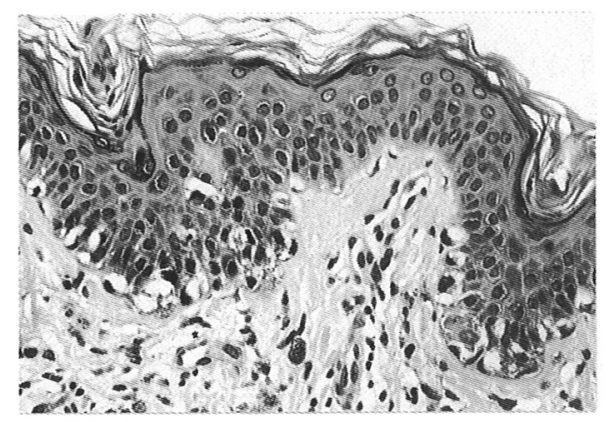

図 4.病変の組織像 $($ H.E.染色 $\times 400)$ メラノサイトの色素産生は著明に亩進し，放 出されたメラニン顆粒が角層内にも残留して みられた 


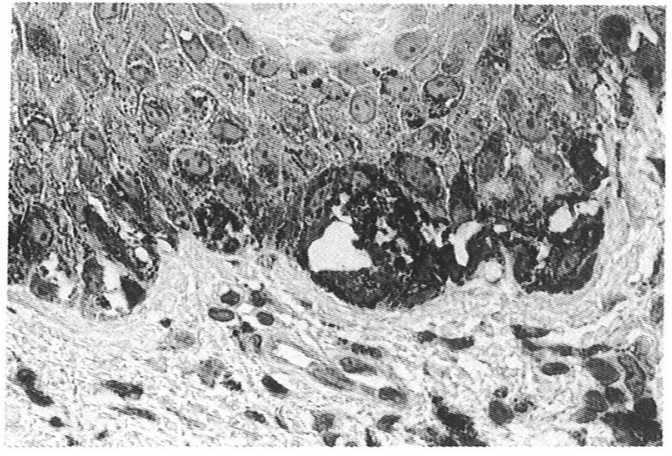

図 5.HMB-45染色像 $(\times 800)$

抗 HMB-45抗体による染色では，異型メラ， サイトの細胞質に一致して陽性コントロール $\mathrm{MM}$ と同様の強い陽性所見を示した

\section{考按}

皮膚原発の $\mathrm{MM}$ の前駆病変について, Clark らは，その多くは色素性母斑が良性・悪性境界 病変を経て $\mathrm{MM}$ へ段階的に移行するものと考 之, 境界病変の特殊な型を dysplastic nevus と して報告した1)。しかし，Ackerman らは，表皮 内メラノサイトが形質転換したことによる悪性 化病変が $\mathrm{MM}$ in situ であり, $\mathrm{MM} の$ 初期病変 であると主張した2)。現在では, MM のほとんど は色素性母斑とは関係なく，表皮メラノサイト から de novoに発生し, MM in situの段階を 経て浸潤性の MM に進展していくとする Ackerman らの考之 ${ }^{23)}$ が支持されている。

さて，MMの早期病変すなわち Early melanoma(EM)は, 現在 MM in situ と tumor thickness が1mm 未満のものとされている が4)，一般に EM とりわけ MM in situ は，病変 が小さいので，臨床的ならびに病理組織学的に 診断が困難であるとされている5)。

従来, MM 早期病変の発見に有用な臨床的診 断基準(67)のなかでも，最大径が $6 \mathrm{~mm}$ 以上であ ることが有力な目安である ${ }^{8}$ とされてきた。事 実, 本邦では最大径 $6 \mathrm{~mm}$ 未満の $\mathrm{MM}$ の報告は 自験例を含めて 4 例9)10)しかなく，国外でも6 $\mathrm{mm}$ 以下の $\mathrm{MM}$ は $\mathrm{MM}$ 全体の $1 \%$ に満た

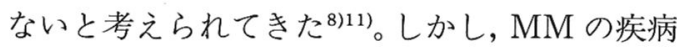
対策として早期診断・早期治療に力を入れるよ うになった1990年以降は違う結果が出ている。 オーストラリアの 1,150 例の MM では, 約 $1 / 3 の$ 358例は最大径 $6 \mathrm{~mm}$ 以下であり ${ }^{12)}$, Bartoli ら （伊）は，組織学的に MM in situ と診断された 121 病変の $23 \%$ (27例）が6 $\mathrm{mm}$ 未満であったと 述べている13)。したがって，直径が小さく，臨床 的に浸潤を触れないものも含まれるように診断 基準を修正すべきであるという考えもある ${ }^{12)}$

自験例は最大径が $4 \mathrm{~mm}$ と小さいが，診断基 準の，非対称性 (asymmetry in shape)，辺縁 が不整 (border irregularity)，色調の不均一 (color variegation) の 3 項目を満たしており, 臨床的に MM と診断し得る症例と考えた。

組織学的には，表皮内に限局して基底層を中 心に異型メラノサイトが不規則に飛ざ石状に孤 立して散在し，一部では胞巣をなしていた。ま た，異型メラノサイトの分布は非対称性で， lateral margin が鮮明でなかった。Ackerman ら によれば，早期の MM in situ は表皮基底層部 における異型メラノサイトの個別性増殖として 始まるが, 進行に伴い, 部分的に有棘層中〜上 層から角層に至る個別性増殖が顕著となり，大 小不整な胞巣形成も認められるようになる。胞 巣は基底層に限局せず有棘層内にも認められ, 胞巣と周囲の表皮細胞の間に裂隙を形成する傾 向は少ないという2)。したがって，自験例は臨床 的ならびに組織学的に MM in situであり，そ の中でも早期病変と思われた。

ただし，自験例では，早期病変のためか, 異 型メラノサイトの胞巣形成は弱く，さらに表皮 上層への拡大が判然としないため, 境界活性の 強い junctional nevusやいわゆる dysplastic nevus との鑑別が問題ともいえる。しかし，母斑 におけるメラノサイトの分布は, 腫瘍の断端部 までで境界が明らかであり，さらに左右対称性 である ${ }^{14)}$ こから良性の色素性母斑を否定し た。さらに HMB-45の染色結果も，自験例を 
MM と考えさせるものであった。

ところで, Bartori らは MM in situの臨床像 について, 病変が非対称性のものが $87 \%$, 境界 不整なものが $88 \%$, 色調が不均一なものが $98 \%$, 最大径が $6 \mathrm{~mm}$ 以上のものが77\%であり, 進展 した MM との間に大きな相違はないとしてい る ${ }^{13)}$ 。しかし, 隆起性病変が僅かに $8 \%$ である 点，また約半数は黒色調を呈するものの，残り 半数が褐色ないしは黄褐色である点が注目すべ き相違点と考えられる。

MM in situの治療は, 転移の怖れが少ないこ とから, 化学療法などの補助療法と所属リンパ 節の郭清は不要とされ, 切除範囲は, 一応の目 安として辺縁から $5 \mathrm{~mm}$ 以上離し, 皮下脂肪織 のレベルで切除し, 断端に腫瘍細胞の露出がな いことを確認すれば十分であるとされてい る5)。ただし, 切除の際にマージンが $3 \mathrm{~mm}$ 前後 しかない症例や, 病変の最大径が $30 \mathrm{~mm}$ を越之 る症例では, in situ 病変であっても, 局所再発 をみる場合があるという'13)

MM in situは, MM ではあるが，ほとんど の症例が生物学的に良性の病変と考えられる。 ただし，本邦では MM in situの段階での報告 例が非常に少なく，境界活性の強い境界母斑と されている可能性もある。最大径が $6 \mathrm{~mm}$ 未満 であっても，MM を疑わす所見があれば，切除 範囲は $5 \mathrm{~mm}$ 以上，深さは皮下脂肪レベルとし て積極的に外科的治療を行うべきであると考え られる。

\section{文献}

1 ) Clark, W.J.Jr., Elder, D.E., Guerry, D.IV, et al. : A study of tumor progression: The precursor lesion of superficial spreading and nodular melanoma. Hum Pathol., 15 : 1147-1165, 1984.

2) Kamino, H., Ackerman, A.B.: Malignant melanoma in situ: The evolution of malignant melanoma within the epidermis. Pathology of malignant melanoma, Ed. Ackerman, A.B., New York, Masson Inc., 1981, pp59-91.

3 ) Saida, T.: The concept of de novo origin of cutaneous malignant melanoma, Eur. J. Dermatol., 4 : 252-254, 1994.

4) NIH Consensus Development Panel on Early Melanoma : Diagnosis and Treatment of Early Melanoma, JAMA., 268 : 1314-1319, 1992.

5 ) 河内繁雄, 斎田俊明：皮膚悪性黑色腫の早期病 変：概念と診断および治療. Skin Cancer, 7 : 367-372, 1996.

6 ) Rigel, D.S., Friedman, R.J., Kopf, A.W. : Early detection of malignant melanoma: the role of physician examination and self-examination of the skin. CA, $35:$ 130-151, 1985.

7 ) Fitzpatrick, T.B., Rhodes, A.R., Sober, A.J., et al. : Primary malignant melanoma of the skin: the call for action to identify person at risk ; to discover precursor lesions; to detect early melanoma. Pigment Cell, 9 : 110-117, 1988.

8 ) Schmockel, C., Braun-Falco, O.: Diagnosis of early melanoma: sensivity and specificity of clinical and histological criteria. Pigment Cell, 8: 96-106, 1987.

9 ) Ban, M., Yoneda, K., Yanagihara, M., et al. : A case of superficial spreading melanoma in situ 2.5mm in diameter. J. Dermatol., 20: 432-435, 1993.

10）小口真司, 徳田安康, 松本和彦, 他: Malignant Melanoma in situ の 1例, 臨皮, 46:937-940, 1992.

11) Kamino, H., Kiryu, H., Ratech, H.: Small malignant melanomas: Clinicopathologic corelation and DNA polidy analysis. J. Am. Acad. Dermatol., 22 : 1032-1038, 1990.

12) Helen, M.S., McCarthy, W.H. : Small-diameter malignant melanoma : A common diagnosis in New South Wales, Australia. J. Am. Acad. Dermatol., 27 : 679-682, 1992.

13) Baltori, C., Bono, A. et al. : Clinical Diagnosis and Therapy of Cutaneous Melanoma In Situ. Cancer, 77 : 888-892, 1996.

14) Ackerman, A.B., Mendonça, A.M. and Guo, Y. : Differential Diagnosis in Dermatopathology I, 2nd ed., Lea \& Febiger, Philadelphia, 1992, 146149 . 